Please quote as: Lehmann, K.; Söllner, M. \& Leimeister, J. M. (2016): Increasing Learner Interaction in Large-Scale Lectures by Using a Mobile-Learning Application. In: Mobile and Blended Learning Innovations for Improved Learning Outcomes.

Hrsg./Editors: Parsons, D. Verlag/Publisher: IGI Global, Hershey, PA.

Erscheinungsjahr/Year: 2016. 


\title{
Chapter 6 \\ Increasing Learner Interaction in Large-Scale Lectures by Using a Mobile Learning Application
}

\author{
Katja Lehmann \\ University of Kassel, Germany \\ Matthias Söllner \\ University of St. Gallen, Switzerland \& University of Kassel, Germany \\ Jan Marco Leimeister \\ University of St. Gallen, Switzerland \& University of Kassel, Germany
}

\begin{abstract}
Universities face increasing numbers of students leading to increasingly large lectures, and decreasing interaction and feedback, which are important factors for individual learning success and satisfaction. The use of IT can help in overcoming this challenge by increasing the interaction in large-scale lectures without massively increasing the workload of lecturers. This paper presents the design, use and evaluation of a mobile-learning application aiming to increase the interaction in large-scale lectures and the success of learners. For designing the application, the authors follow a design science research approach. The authors rely on insights from interaction theory as well as requirements gathered from lecturers and students in a focus group workshop. With the implementation, large-scale lecture related limitations can be overcome and the results help lecturers to face the according challenges. The results emphasize the potential of IT for university teaching and provide transferable insights for practical use in other learning scenarios.
\end{abstract}

\section{INTRODUCTION}

Universities in many western countries face increasing numbers of students. As a result, growing numbers of learners in lectures and an unfavorable lecturer-to-students-ratio of up to 80 students per lecturer is a common situation. These large-scale lectures are characterized by high anonymity and suffer from a

DOI: $10.4018 / 978-1-5225-0359-0 . c h 006$

Copyright $\odot$ 2016, IGI Global. Copying or distributing in print or electronic forms without written permission of IGI Global is prohibited. 
lack of interaction - not only among learners themselves but also among learners and lecturers. Moreover collaborative learning is not feasible in traditional large-scale lectures, where learners are single learners (Lehmann and Leimeister, 2015). The results of this decreasing interaction are often deficient learning outcomes and unsatisfied learners. For example, comprehension questions regarding the lecture as well as discussions on specific topics are not feasible, as they are impractical. This development is alarming, since fundamental elements of learning success include the opportunity to ask questions and the possibility of sharing one's opinions concerning the subject matter (Picciano, 2002). Additionally, interaction and feedback are regarded as significant predictors in terms of the learning success (A. Moore et al., 1996) and positively influence the long-term satisfaction of learners (Alonso et al., 2009; Hardless et al., 2005). It is true that by being actively engaged in the learning-teaching process, learners will get a deeper comprehension of the subject matter (Evans and Gibbons, 2007). But bringing interaction in a large-scale-lecture is a widespread problem (Lehmann et al., 2015).

A promising possibility to increase the interaction without massively increasing the workload of lecturers is the use of IT. Several researchers have investigated the possibility of mobile technologies to improve the classroom situation (Ratto et al., 2003). With the aid of IT and mobile devices, interactive data can be transferred between students and lecturers in real-time, which provides potential for improving the interaction in lectures (Dyson et al., 2009; Wortmann et al., 2014), for intervening in the learning-teaching process and enriching traditional courses. The application of IT supported learning and teaching has increased recently in education (Johnson et al., 2012). The use of mobile devices is widespread. They are flexible in use, easy to use and allow synchronous and asynchronous communication (Lehmann et al., 2012). The current state of research shows that existing learning applications do consider only single types of interaction but not all three types of interaction, which are proposed by Moore (1989) and no learning application exists which consider interaction completely.

The goal of the present research is to develop a mobile-learning application to increase interaction in large-scale lectures. Particularly, by using the mobile-learning application, learners should interact more with the learning content, the lecturer, and among each other. Hence, all three interaction types proposed by Moore (1989) are addressed.

Therefore, this paper aims to examine the following research questions (RQ):

RQ 1: How should the mobile-learning application be designed to increase interaction in the learningteaching process of a large-scale lecture?

RQ 2: Is the mobile-learning application perceived as helpful in terms of quality, usefulness and satisfaction?

RQ 3: How does the frequency of use of the mobile-learning application affect the interaction among the students in a university large-scale lecture?

In order to answer the research questions, the chapter is structured as follows. The second part of the chapter presents the research methodology. Afterwards the related work part on mobile-learning applications is described. Then, the authors rely on insights from theory of interaction in order to gather theoretical requirements and they conduct a focus group workshop to gather practical requirements. Accordingly, the sixth part describes the design and development of the mobile-learning application. Section 7 presents the results as answers to the second and third research questions, before section 8 discusses the relevant results. Finally, the chapter closes with a conclusion, the implications, as well as limitations and an outlook on future research. 
Figure 1. Research approach for developing the mobile-learning application Source: Adopted from Peffers et al. (2006)

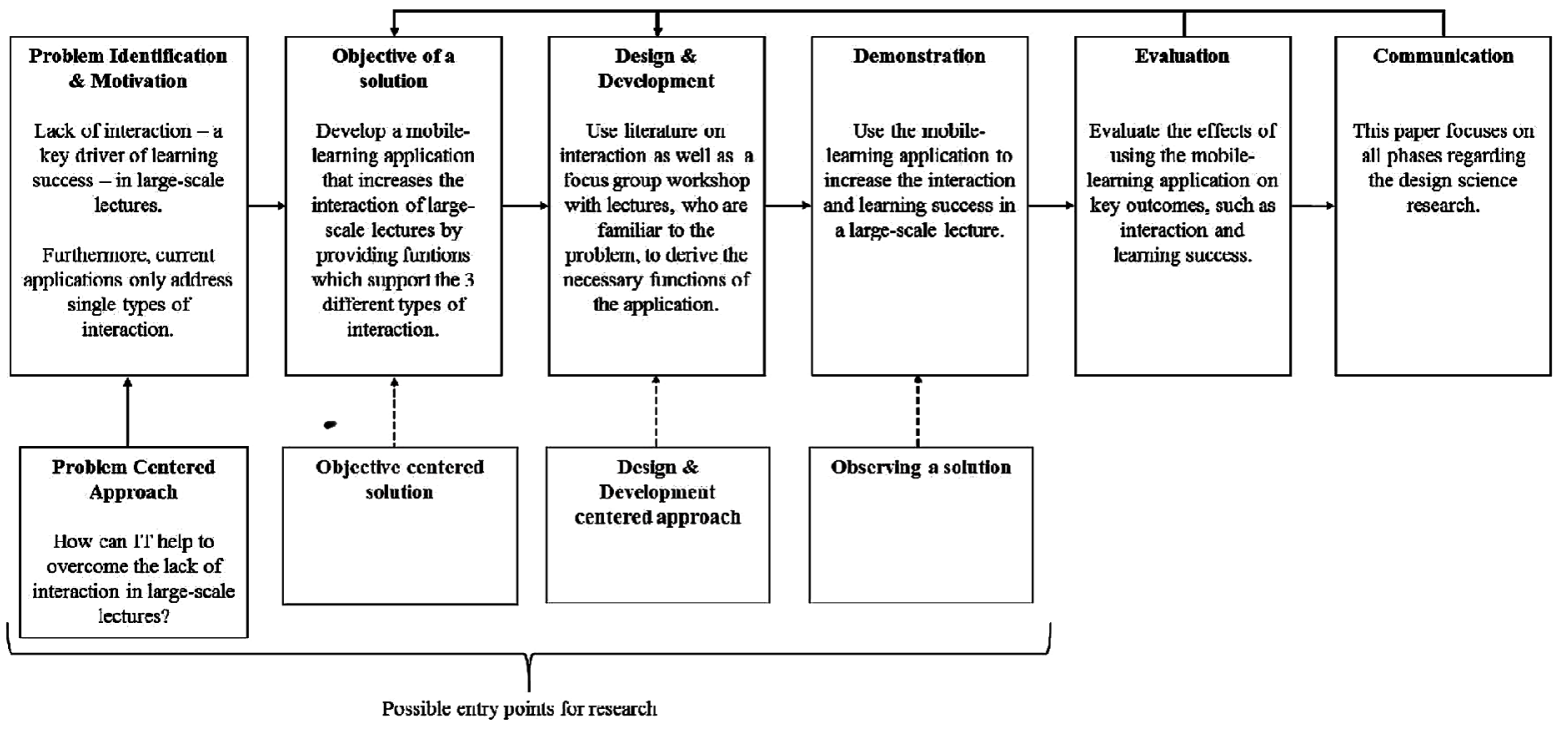

\section{RESEARCH METHODOLOGY}

The goal of the research is to develop a mobile-learning application which enables a robust and operational interaction between learners and lecturers as well as among the learners themselves in large-scale lectures. To achieve the research goal, the authors follow the design science approach (Hevner et al., 2004; Peffers et al., 2006), particularly the design science research approach of Peffers et al. (2006) (see Figure 1). Moreover, to ensure that the application addresses all important types of interaction, the authors follow Briggs (2006) theory-driven design approach, by grounding the research in theory on interaction. This paper presents details on all phases advocated by Peffers et al. (2006) for the development of the mobile-learning application. The introduction has addressed the phase problem identification and motivation. The next two sections describe the objectives of a solution phase by identifying requirements from theory of interaction and from a focus group workshop. The authors then provide details on the third phase, design and development of the mobile-learning application. Afterwards they present evaluation results which emphasize the demonstration and evaluation phase.

\section{RELATED WORK}

Mobile learning is a type of eLearning, which utilizes mobile devices, and makes learning flexible, spontaneous and portable (Kukulska-Hulme and Traxler, 2005). Hereby, the term mobile encompasses learning with the aid of devices outside educational institutions. The integration of such devices in a traditional course refers to blended learning (Duncan-Howell and Lee, 2007). One large advantage of mobile devices is their flexible usage: they can be used in class without any organizational effort (e.g. booting time, special computer labs) (Wessner and Dawabi, 2004). In traditional courses the use of 
mobile devices offers the possibilities to improve the interaction between the lecturer and the student, or that among the students. It can also help to enhance the participation of the learners, and the quality of teaching (Wessner and Dawabi, 2004).

Classtalk was one of the first applications which were used in lectures pursuing the aim to create a more interactive, learner-centered classroom. The application enhances communication in class, presented questions for small group work and collected students answers for displaying them (Dufresne et al., 1996). The project ConcertStudeo activates students by means of handheld-computer, an electronic blackboard and PDAs for the students with brainstorming, a quiz, voting or ranking (Dawabi et al., 2003). Using audience response systems or clickers (e.g. Turning Point), as they are commonly called, students are able to answer questions in the form of quizzes or self-assessments and are able to provide feedback (Kenwright, 2009). In a contribution made by Wessner und Dawabi (2004) two systems (Haake and Wessner, 2004; Roschelle et al., 2002) are examined using specific design questions (e.g. integration in the learning scenario, distribution of information, interaction). Their results are that both applications are suitable to keep the traditional course advantages but enrich those lectures with different interaction opportunities (Wessner and Dawabi, 2004). One application of the Wake Forest University (Class-In-Hand) offers students the opportunity to answer a quiz via web browser or to provide feedback to a statement on a scale. Thereby the communication is unidirectional from the students to the lecturer (Scheele et al., 2004). Another type of student-response-system was realized in form of the web application Swatt to provide questions in a multiple-choice, true-false, or yes-no format to the students for answering (Shotsberger and Vatter, 2001). Similar to a multiple-choice format is the method Peer Instruction created by a Harvard professor. Besides answering a short conceptual question interspersed by the teacher, the students should discuss about the question to their colleagues (Fagen et al., 2002). The application of Peer Instruction is carried out using mobile devices, i.e., in the project Pingo (Reinhardt et al., 2012).

Current research focuses on creating the user interface more intuitive and investigate how to use a high quality presentation of images, videos, etc. despite a small screen size without having to leave out relevant content (Kopf et al., 2011; Schon et al., 2012; Van Rijsselbergen et al., 2012). Tabata et al. (2010) focuses on an online learning application for the iPhone to support students in answering knowledge questions regardless of time and place. Clunie et al. (2012) present a platform which makes it possible to connect Android mobile devices with the Learning Management System (LMS) Moodle.

To sum up, use of digital media to enhance and to support teaching, especially large-scale lectures, is not new in IS research. But continuous improvement of lectures quality with digital media is still a trend topic. Moreover, the employment of mobile devices in lectures continues to increase significantly (Johnson et al., 2012). Thus, the number of owners of smartphones and tablets among students is growing. Gartner predicts tablet PC sales will reach 327 million worldwide in 2015. The current state of research shows that there exist a large number of applications to enhance interaction and collaboration. But none of these applications consider a set of functions integrated in a single application to enhance the three types of interaction while simultaneously guaranteeing browser and platform independence. Current standard solutions like LMS Moodle or Blackboard are not delivering liberties in design or technical solutions. The LMS Moodle is used at our university. It is not possible to implement and integrate a new function into Moodle. Furthermore anonymity is not guaranteed using Moodle. These are the reasons for the development of the mobile learning application presented here. It is an entirely new design, and is not based on an already existing application. 


\section{REQUIREMENTS FROM THEORY OF INTERACTION}

The meaning of the term 'interaction' in the disciplines of sociology, education and psychology addresses the interrelation between humans and their communicative actions amongst each other (Bryant and Heath, 2000). IT applications can be used to support and enhance interaction. In this paper the prototype is a mobile-learning application which aims at increasing the interaction between learners and lecturers and among the learners themselves and the learning success in large-scale lectures. Regarding interaction, we specifically refer to the work of Moore (1989), in which the author differentiates between three types of interaction: learner-content-interaction, learner-lecturer-interaction and learner-learner-interaction. We adopt those three types of interaction for our paper and define interaction itself as learning activities, including exchange between learners, lecturers and content (M. G. Moore, 1989; Schrum and Berge, 1997).

Prior research has shown that learners who interact with their lecturers are more actively involved in the learning process (Liu et al., 2003; Wang et al., 1990). The question-answer-game is the classic form of interaction found between learners and lecturers. The lecturer can actively include the learner in teaching, assess the learning progress by means of the answers and provide direct feedback. The learners have the opportunity to contribute their ideas and thoughts, thus, also initiating new thought processes (Gagné et al., 1993; Morgan, 1991). Furthermore, interaction influences the quality of learning in a positive way. A study showing that learners with low or intermediate previous knowledge profit from a high degree of interaction and achieve higher learning results (Snell, 1999).

To increase the interaction, factors which inhibit interaction need to be eliminated. First, when attending large-scale lectures, learners often avoid interaction with lecturers because they fear embarrassment in such an impersonal setting (Ratto et al., 2003; Siau et al., 2006). Second, the seating order of learners (Roth et al., 1999), the limited time for the study unit (VanDeGrift et al., 2002) and the fact that it is hardly ever possible to involve all learners in discussions (Siau et al., 2006) inhibit interaction, especially in large-scale lectures. Some learners could fear holding up the whole auditorium with their specific question (Ratto et al., 2003). As is known from the psychology of learning, both the attention and the motivation of learners decrease after approximately 20 minutes (Smith, 2001). Thus, it is even more important to employ elements in university lectures which have activating functions. An interactive setting in the learning-teaching process can enhance learners' motivation, attention and participation in class, as well as foster greater learners' exchange (Liu et al., 2003; Sims, 2003).

The three types of interaction represent the starting point for deriving requirements. Table 1 presents the general requirements $(\mathrm{R})$ we could identify from theory. These are the basis for developing our mobile-learning application. Requirements formulation from the sentence structure is based on Hull et al. (2010). The requirements formulation argues from the learners' perspective since the learners are the main focus of the mobile-learning application. Moreover, the three interaction types focus on a learner perspective as well. We base our subsequent design decisions on the constructs linked to our phenomena of interest. Summing up, we could identify seven requirements from theory to ensure that all three types of interaction are addressed by our mobile-learning application (Table 1).

\section{REQUIREMENTS FROM A FOCUS GROUP WORKSHOP}

Regarding the goal of rectifying the lack of interaction within universities' large-scale lectures, the authors initiated a lecturers' workshop with eight university lecturers with varying degrees of teaching 
Table 1. Requirements from theory of interaction

\begin{tabular}{|c|c|c|}
\hline Interaction Type & Description & Requirements from Theory (T) \\
\hline $\begin{array}{l}\text { Learner-Learner- } \\
\text { Interaction }\end{array}$ & $\begin{array}{l}\text { This interaction type takes place between one learner and others, alone or in } \\
\text { group settings, with or without the real-time presence of an lecturer (Moore, } \\
\text { 1989). It is described as an extremely valuable resource for the individual } \\
\text { learning (Moore, 1989). Learners should be encouraged to cooperate with } \\
\text { the peers during the learning-teaching process to exchange knowledge (Alavi, } \\
\text { Marakas and Yoo, 2002; Boud and Falchikov, 2007) and for discussions to } \\
\text { enhance motivation (Eisenkopf, 2010) and learning success (Fredericksen, } \\
\text { Pickett, Shea, Pelz and Swan, 2000; Moore and Kearsley, 2011). This } \\
\text { interaction type is not effectively facilitated in large-scale lectures and calls } \\
\text { for specific IT use (Phillips et al. 1988). In collaborative assignments students } \\
\text { learn from each other and create new knowledge mutually (Topping, 2005). }\end{array}$ & $\begin{array}{l}\text { T1) Learners should be creating } \\
\text { learning material collaboratively. } \\
\text { T2) Learners should discuss } \\
\text { among each other. }\end{array}$ \\
\hline $\begin{array}{l}\text { Learner-Lecturer- } \\
\text { Interaction }\end{array}$ & $\begin{array}{l}\text { In this type of interaction, the lecturer attempts to achieve teaching aims } \\
\text { regarding the learning content (M. G. Moore, 1989). Moreover, the lecturer } \\
\text { seeks to enhance the learner's interest, including self-direction and self- } \\
\text { motivation (M. G. Moore, 1989). The lecturer still plays a significant role for } \\
\text { learning success as well as satisfaction (Eom et al., 2006). Lectures should } \\
\text { give advice and feedback to learners and need to retain an overview of their } \\
\text { individual performance (Bligh, 1998). In addition, the teacher should verify } \\
\text { which learning goals have been achieved or may not have been achieved. In } \\
\text { interaction with lecturers, students can request clarification of unclear points } \\
\text { and lecturers can reinforce correct interpretation (Thurmond and Wambach, } \\
\text { 2004). }\end{array}$ & $\begin{array}{l}\text { T3) Learners should receive } \\
\text { feedback. } \\
\text { T4) Learners should provide } \\
\text { feedback. } \\
\text { T5) Learners should have the } \\
\text { possibility to ask questions } \\
\text { regarding unclear points. }\end{array}$ \\
\hline $\begin{array}{l}\text { Learner-Content- } \\
\text { Interaction }\end{array}$ & $\begin{array}{l}\text { This type of interaction contains what Holmberg (Holmberg, 1986) calls the } \\
\text { "internal didactic conversation" when learners talk to them-selves regarding } \\
\text { the learning content (Moore, 1989). Moreover, this interaction form takes } \\
\text { place when learners participate in class activi-ties (Thurmond and Wambach, } \\
\text { 2004). Learning materials should be designed in an activating way to } \\
\text { support peer learning and it should be developed with regard to instructional } \\
\text { and multimedia design guidelines (Clark and Mayer, 2008). Assignments } \\
\text { regarding the learning content should be integrated in class. Factors that affect } \\
\text { the learner-content-interaction can be contact with the content (Leasure, Davis } \\
\text { and Thievon, 2000) and participation in class discussions (Jiang and Ting, } \\
\text { 1999). }\end{array}$ & $\begin{array}{l}\text { T6) Learners should get content } \\
\text { specific assignments. } \\
\text { T7) Learners should get content } \\
\text { specific assignments to discuss. }\end{array}$ \\
\hline
\end{tabular}

experience in large-scale lectures. The utilization of focus groups aims to generate numerous innovative ideas (Greenbaum, 1998). To guarantee a systematic collaboration, the authors chose the collaboration process design approach from Kolfschoten and De Vreede (2009). The task of the workshop was to gather ideas for activating elements for the mobile-learning application to improve the interaction in large-scale lectures at universities. The first activity performed in the workshop was brainstorming in order to collect a variety of ideas to reduce the lack of interaction. In a moderated discussion, each idea was discussed with participants, the redundant ideas were eliminated, and the remaining ideas were evaluated using a Likert scale. Afterwards, the ideas that received the highest scores in the evaluation were discussed. The discussion results in four ideas that the authors afterwards used to derive concrete requirements for the mobile-learning application. The practical requirements $(\mathrm{P})$ are the following:

P1: Even in mass settings learners should have the possibility to provide feedback to the lecturer to incomprehensible learning content.

P2: Learners should be able to ask questions to their lecturer anonymously. 
Figure 2. Screenshot of the functions of the learners' application
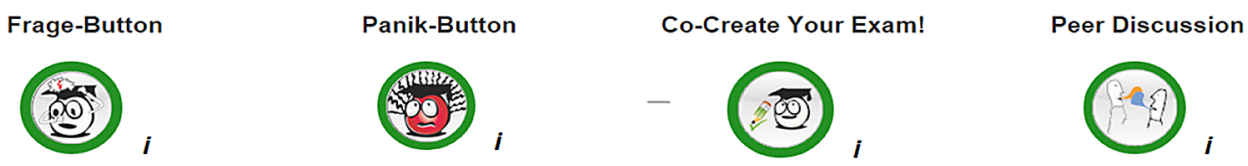

Figure 3. Screenshot of the functions of the lecturers' application
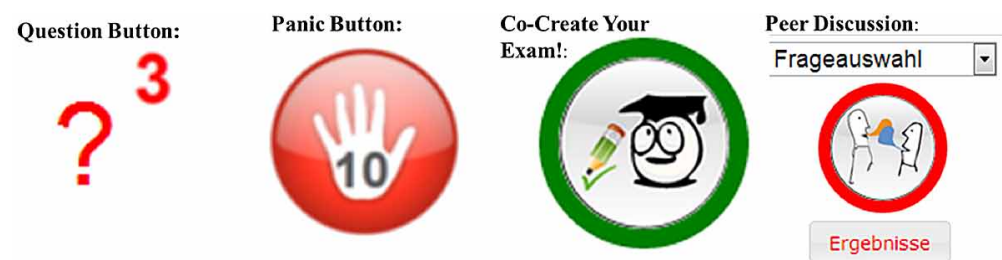

P3: Learners should create true/false-statements to deal with the learning content and exchange those with their fellow students.

P4: Lecturer should provide questions to the learners who answer and discuss them with their fellow students.

\section{DESIGN AND DEVELOPMENT OF THE MOBILE-LEARNING APPLICATION}

The mobile-learning-application aims to increase activation among a large number of learners, while allowing for a stable interactivity format ready for use even in large-scale lectures (Lehmann et al., 2012). Parallel to the development of the prototype, evaluations involving university lecturers and students took place in iterative cycles. At regular intervals the functions were designed, implemented and tested. The goal of the conducted evaluation was to monitor the graphic preparation of the individual functions. This approach is typical for the so-called participatory design (Pilemalm and Timpka, 2008), which is an approach that centers on the user. Consequently, the user is involved as an active participant in the planning, presentation and evaluation of the design process (Pilemalm and Timpka, 2008). Four to six people suffice for each evaluation round in order to obtain a reliable assessment of the results (Nielsen, 1994). The objective regarding the graphical preparation of the individual functions was to realize an intuitive and practical interface which is very easy to use. Lecturers, e.g., prefer to obtain all relevant information for the lecture on a single screen. This guarantees that lecturers are still able to view and control the presentation and use their notes and, at the same time, are still able to monitor the information about the current setting. Moreover it makes it unnecessary to switch between several programs. Based on Olivia (2004), a simple yet clear design should be selected in order to reduce non-data pixels and visual complexity. Every function in the mobile-learning application is represented by a simple, but very characteristic and easily recognizable symbol. This is especially important to avoid a further increase in the cognitive load of the lecturers, to not inhibit the actual transfer of knowledge. The mobile-learning application is separated in two views; one view for the learners and another view for the lecturer. The following figures 2 and 3 show an extract of the application; separated into the two views. 


\section{Specific Description of the Functions}

The functions in the mobile-learning application are aimed at increasing the activation and enabling a robust and operational interaction. The design of the functions is the final result of the participatory design aiming an ease of use for the users. Students are able to use the application place synchronous or place asynchronous, since the lecture is broadcasted via livestream during the class. Access to the application for both students and lecturer is via a URL. There is no ex ante registration necessary to ensure anonymity (Bitzer et al., 2012). In Table 2 the four functions are described. The embedding of activating functions in a large-scale lecture stops passiveness during lecturing (Snell, 1999). All functions aid the realization of interaction, which Moore (1989) differentiates.

The Question Button allows for an anonymous communication between students and lecturers, thus avoiding factors which may limit interaction in the learning-teaching process. The Question Button is applicable in- and outside the in-class lecture. Parallel to the lecture, incoming questions are answered in class by the lecturer. Additionally, automatic e-mail forwarding to the lecturer is set up in the system for the Question Button. This allows students to ask questions outside the class. Outside the class, incoming questions will answer via the accompanying LMS Moodle forum.

Table 2. Description of the functions of the mobile-learning application

\begin{tabular}{|c|c|c|c|}
\hline & Functionality & Design & $\begin{array}{l}\text { Theoretical (T) } \\
\text { and Practical (P) } \\
\text { Requirements }\end{array}$ \\
\hline $\begin{array}{l}\text { Question } \\
\text { Button }\end{array}$ & $\begin{array}{l}\text { Students can send their questions to the lecturer anonymously. } \\
\text { The questions are answered by the lecturer during class or in } \\
\text { the class-concomitant forum. In addition, the system allows } \\
\text { automatic email forwarding from incoming questions to the } \\
\text { lecturer. }\end{array}$ & $\begin{array}{l}\text { The number of incoming questions } \\
\text { asked by the learners via the Question } \\
\text { Button light up red for the lecturer } \\
\text { and can be read from the lecturer in a } \\
\text { separate window in chronological order. }\end{array}$ & $\begin{array}{l}-\mathrm{T} 5 \\
-\mathrm{P} 2\end{array}$ \\
\hline $\begin{array}{l}\text { Panic } \\
\text { Button }\end{array}$ & $\begin{array}{l}\text { Students can press the Panic Button to send a signal to the } \\
\text { lecturer about ambiguous learning content. The button can be } \\
\text { used during the whole lecture. }\end{array}$ & $\begin{array}{l}\text { The Panic Button lights up orange on } \\
\text { the lecturer's application if it has been } \\
\text { clicked by a learner. If a predetermined } \\
\text { number is exceeded, the button will } \\
\text { light up in red as a special signal to the } \\
\text { lecturer. }\end{array}$ & $\begin{array}{l}-\mathrm{T} 4 \\
-\mathrm{P} 1\end{array}$ \\
\hline $\begin{array}{l}\text { Co-Create } \\
\text { Your Exam }\end{array}$ & $\begin{array}{l}\text { To a certain time in class students generate true or false } \\
\text { statements dealing with the content they just heard. Statements } \\
\text { are answered and evaluated by colleagues. Moreover the } \\
\text { lecturer gets randomly selected statements for answering and } \\
\text { evaluating using a projector. The application allows exporting } \\
\text { the generated statements. They are then available via the } \\
\text { university's LMS and students can use them as exercises. To } \\
\text { a certain extent, the statements are used for the exam, thus } \\
\text { enhancing the incentive for learners to work with the learning } \\
\text { content and produce high quality statements. }\end{array}$ & $\begin{array}{l}\text { Using the button for Co-create Your } \\
\text { Exam! opens new windows for in- and } \\
\text { output in both applications. Learners } \\
\text { and lecturers can rank statements with a } \\
\text { five-point-star-rate. }\end{array}$ & $\begin{array}{l}-\mathrm{T} 1, \mathrm{~T} 6 \\
-\mathrm{P} 3\end{array}$ \\
\hline $\begin{array}{l}\text { Peer } \\
\text { Discussion }\end{array}$ & $\begin{array}{l}\text { The lecturer can send single-choice questions with five } \\
\text { predetermined answers to the students. First of all each student } \\
\text { answers the question alone. Second, each student shall discuss } \\
\text { the question to their colleague. Third, each student has to } \\
\text { answer the question again. The lecturer can hereby evaluate the } \\
\text { learning success of the students and give them direct feedback. }\end{array}$ & $\begin{array}{l}\text { The results of the vote are calculated } \\
\text { in real-time and can be shown by the } \\
\text { lecturer using a projector. The Peer } \\
\text { Discussion is the only one that must } \\
\text { be activated by the lecturer and is not } \\
\text { available for using outside class. }\end{array}$ & $\begin{array}{l}\text { - T2, T3, T7 } \\
\text { - P4 }\end{array}$ \\
\hline
\end{tabular}


The Panic Button aims to provide lecturers a response to the transfer of knowledge. After being pressed by a student, the Panic Button lights up in orange on the lecturer application. When exceeding a predefined number the button lights up in a bright red as a special signal for the lecturer. This is in line with literature suggestions on demonstratively highlighting important information (Yigitbasioglu and Velcu, 2011). By pressing the button, the lecturer may reset this number.

Similar to the Question Button, a new window for input and output opens in both applications when using the Co-Create Your Exam. The co-created true-false statements generated by the students are uploaded in the form of accessible tasks to the LMS. Some of the statements are to be used in the exam as an incentive for the students to reflect on the learning content and to create genuine statements. In addition to these activation effects, the students create a data pool of reusable tasks. The lecturer may additionally store the student solutions in other programs in the long term by means of export features for the Question Button and the Co-Create Your Exam.

When pressing the button for Peer Discussion, new windows for input and output open on the student as well as the lecturer applications. The Peer Discussion allows the students to pick one out of five possible answers. The voting result is determined in real time and presented by the lecturer via the projector. Thus, the lecturer may assess the learning success of the students before providing according feedback. The present IT support additionally enables the lecturer to store the response assessment as a result documentation, possibly to be used for post-processing.

Co-Create Your Exam and Peer Discussion allow the students to reflect on the learning contents in class rather than merely adapting them. All four functions implement the three types of interaction differentiated by Moore (1989). The lecturer, in turn, receives important information on the current learning success of the students, allowing for a more specific recognition of deficits and a repetition of learning contents.

The lecture comprises activation phases designed by the lecturer, who unlocks parts of the activating functions (Peer Discussion only). The other activating functions (Question Button, Panic Button, and CoCreate Your Exam) are continuously available to the students. Co-Create Your Exam and the Question Button may additionally be used outside the class. The Panic Button is only useful during the lecture.

The extensive IT support requires suitable terminal equipment from the learners. In the present case, the learners could borrow a tablet or netbook for the duration of the semester to access and use the mobilelearning application during the learning-teaching process. Learners were allowed to take the mobile devices home. This guarantees a use of the mobile-learning application inside and even outside the class.

\section{Conception of Technology}

The authors designed and implemented both mobile-learning applications (learners, lecturer) as web applications. The lecturer application was developed by means of traditional web technologies/scripting languages such as PHP5, HTML5, CSS3, and JavaScript. MySQL was used as relational database management system. In order to guarantee platform independence on the part of the learners while supporting $\mathrm{iOS}$ and Android-based mobile end devices in addition to computers, we developed the learner application on the basis of the jQuery Mobile framework, thus allowing for the application to be used via all prevalent internet browsers as well as smartphones and tablets. 


\section{EVALUATION RESULTS AND DISCUSSION}

To evaluate the mobile-learning application regarding the research questions data from two different semesters but from the same lecture were taken. The lecture is an IS introductory large-scale lecture for undergraduate students which is held every semester at a German university. In the first semester the authors conducted a pre-test of the mobile-learning application and gathered data regarding quality, usefulness, and satisfaction because the research intention was to examine whether the mobile-learning application is ready for being used. In the following semester the authors started to establish the mobilelearning application in the IS introductory lecture and gathered data to answer research question 3 . The application was used over the whole semester. The goal focuses on investigating whether the frequency of use of the mobile-learning application affects the interaction among the students in the university large-scale lecture.

\section{Results Regarding Research Question 2}

To assess quality of the mobile-learning application, the authors conducted an evaluation aiming to answer the question whether the application is ready for being used in a large-scale lecture. Therefore, the authors used the application at the end of a large-scale lecture in an IS introductory lecture for undergraduate students. The students received an introduction on the functions of the mobile-learning application, could access it via their mobile devices and were asked to use it during the lecture. Participation was voluntary. The lecture was designed in a way that all functions of the application could be used. Afterwards, the students were asked to complete a questionnaire containing the necessary items for the evaluation. All items were measured using a bipolar five-point Likert response format with the endpoints labelled as "I disagree" and "I agree". In total, 49 questionnaires of the 85 class-attendees (response rate 58\%) could be used for our evaluation.

Due to authors' interest on quality, usefulness, and satisfaction of the mobile-learning application, and the fact that there was no incentive for the students to complete the questionnaire but their goodwill, the authors decided to keep the items to a minimum and focused on the following constructs: Perceived Usefulness (PU), User Satisfaction (US), and Perceived Presentation Quality (PPQ) for the overall application. Furthermore, the authors assessed the Performance Expectancy (PE) and Intention to Use (IU) for every function to gather more detailed feedback on the quality of different functions. The results of the evaluation are presented in Table 3. To evaluate the research question, a t-test was used and the tool of analysis was SPSS 22.

Regarding the measurement of the constructs, the authors relied on scales provided by previous studies. Furthermore, the values for Cronbach's Alpha and indicator loadings fulfilled the requested thresholds (Chin, 1998; Nunnally, 2010). Further, the mean values for all but one constructs are significantly higher than the neutral point of the scale ("neither agree nor disagree"). This indicated a high PE and IU of all but one function of the mobile-learning application. Only the Panic Button received comparably low scores for both, PE and IU. The overall application received high values for PU, US and PPQ. Consequently, the mobile-learning application in general is ready for being used in a large-scale lecture, and perceived as helpful in terms of quality, usefulness and satisfaction. But the usefulness, design and presentation of the Panic Button should be reinvestigated.

The results of the t-test regarding the Panic Button did not show satisfactory results. Possibilities could be different students' learnings styles. Another reason could be inaccurate feedback from the 
Table 3. Evaluation of measurement model and summary statistics $(N=49)$

\begin{tabular}{|c|c|c|c|c|c|}
\hline Construct & $\begin{array}{l}\text { No. of Items } \\
\text { (References) }\end{array}$ & Mean & $\begin{array}{l}\text { Standard } \\
\text { Deviation }\end{array}$ & $\begin{array}{c}\text { Cronbach's } \\
\text { Alpha }\end{array}$ & $\mathbf{t}(\mathbf{d f})=\mathrm{t}$-value \\
\hline $\begin{array}{l}\text { Performance Expectancy - } \\
\text { Question Button }\end{array}$ & \multirow{4}{*}{$\begin{array}{l}4 \text { (Venkatesh et } \\
\text { al., 2003) }\end{array}$} & 3.51 & 1.40 & .910 & $\mathrm{t}(48)=3.530 * * *$ \\
\hline $\begin{array}{l}\text { Performance Expectancy - } \\
\text { Panic Button }\end{array}$ & & 3.18 & 1.40 & .960 & $\mathrm{t}(48)=1.220$ \\
\hline $\begin{array}{l}\text { Performance Expectancy - } \\
\text { Co-Create Your Exam }\end{array}$ & & 3.92 & 1.13 & .937 & $\mathrm{t}(48)=6.262 * * *$ \\
\hline $\begin{array}{l}\text { Performance Expectancy - } \\
\text { Peer Discussion }\end{array}$ & & 3.62 & 1.31 & .960 & $\mathrm{t}(48)=3.919 * * *$ \\
\hline $\begin{array}{l}\text { Intention to Use - } \\
\text { Question Button }\end{array}$ & \multirow{4}{*}{$\begin{array}{l}4 \text { (Söllner et al., } \\
2012 \text { ) }\end{array}$} & 3.64 & 1.32 & .979 & $\mathrm{t}(48)=3.508 * * *$ \\
\hline $\begin{array}{l}\text { Intention to Use - } \\
\text { Panic Button }\end{array}$ & & 3.42 & 1.44 & .973 & $\mathrm{t}(48)=2.192 * *$ \\
\hline $\begin{array}{l}\text { Intention to Use - } \\
\text { Co-Create Your Exam }\end{array}$ & & 4.08 & 1.20 & .978 & $\mathrm{t}(48)=6.517 * * *$ \\
\hline $\begin{array}{l}\text { Intention to Use - } \\
\text { Peer Discussion }\end{array}$ & & 4.08 & 1.10 & .981 & $\mathrm{t}(48)=7.054 * * *$ \\
\hline $\begin{array}{l}\text { Perceived Usefulness - } \\
\text { Mobile-learning Application overall }\end{array}$ & 6 (Davis, 1989) & 3.99 & 1.01 & .971 & $\mathrm{t}(48)=7.336^{* * *}$ \\
\hline $\begin{array}{l}\text { User Satisfaction - } \\
\text { Mobile-learning Application overall }\end{array}$ & 7 (Arbaugh, 2000) & 4.11 & 1.03 & .967 & $\mathrm{t}(48)=7.660 * * *$ \\
\hline $\begin{array}{l}\text { Perceived Presentation Quality - } \\
\text { Mobile-learning Application overall }\end{array}$ & $\begin{array}{l}3 \text { (Wells et al., } \\
2011 \text { ) }\end{array}$ & 3.90 & 0.81 & .950 & $\mathrm{t}(48)=8.195^{* * *}$ \\
\hline
\end{tabular}

Significance with $* \mathrm{p}=<0.05 / * *=\mathrm{p}<0.01 / * * *=\mathrm{p}<0.001$

teacher which didn't map on students' expression while using that button. Consequently, this button needs to ad-just. One idea from a lecturer was to adopt each panic vote to a specific slide in the lecture material. That will give a direct feedback to the learning material. That will give a direct feedback to the learning material.

After the results of the first evaluation of the mobile-learning application shows satisfactory results the authors conclude that the mobile-learning application is ready for being used in the large-scale lecture. For the following semester the authors started to establish the mobile-learning application in the IS introductory lecture and gathered data to answer the third research question.

\section{Results Regarding Research Question 3}

Research question 3 focuses on investigating whether the frequency of use of the mobile-learning application affects the interaction among the students in the university large-scale lecture. The mobile-learning application was applied in each lecture unit over the whole semester. At the semesters' end an online questionnaire was provided via the LMS to be answered by the students. Participation was voluntary. The online questionnaire was completed by 49 students, who all participated in the exam. The sample of $\mathrm{N}=49$ is sufficient for obtaining representative results (Greene and Zhang, 2003). From a total of 243 exam participants the response rate is $20.2 \%$. The constructs to measure interaction were adapted from 
Increasing Learner Interaction in Large-Scale Lectures by Using a Mobile Learning Application

Table 4. Descriptive results: Comparison of mean value and standard deviation

\begin{tabular}{|l|c|c|c|}
\hline \multicolumn{1}{|c|}{ Construct } & $\begin{array}{c}\text { No. of Items } \\
\text { (References) }\end{array}$ & Mean & Standard Deviation \\
\cline { 1 - 2 } Frequency of Use: Question Button & - & 1.96 & 1.19 \\
\hline Frequency of Use: Panic Button & & 1.61 & 0.99 \\
\cline { 1 - 1 } Frequency of Use: Co-Create Your Exam & & 3.53 & 1.34 \\
\cline { 1 - 2 } Frequency of Use: Peer Discussion & & 3.45 & 1.40 \\
\hline Interaction & & 3.20 & 0.73 \\
\hline
\end{tabular}

Siau et al.(2006). All items were measured using a bipolar five-point Likert response format ranging from $1=$ "I disagree" and $5=$ "I agree". To measure frequency of use the learners were asked to assess their use of each activating function from $1=$ "not very often" to $5=$ "very often".

Table 4 presents the descriptive results with mean value as well as standard deviation with respect to the frequency of use of each activating function as well as mean value and standard deviation for the interaction.

The frequency of use for Question and Panic Button is low. By contrast, Co-Create Your Exam and Peer Discussion suggest a good frequency of use. Both latter functions were applied directly during each lecture, which accounts for the better values. The mean value of interaction appears in a good center span.

In order to assess to what extent the use of the activating functions contributes to the prediction of interaction, the authors conducted a multiple linear regression according to the inclusion method (predictors: the use of the four activating functions, criterion: interaction). The basic requirements for the implementation of a multiple linear regression were considered (Ziegler and Bühner, 2009) and adequately met. All tolerance values are significantly higher than .4 and thus well above the critical value of .1 (Brosius, 2008).

Table 5 illustrates the according regression results (interaction). With an overall $\mathrm{R}^{2}$ of 0.58 (corrected $\left.\mathrm{R}^{2}=.545 ; \mathrm{F}(4.44)=15.362 ; \mathrm{p}<.001 ; \mathrm{N}=49\right)$, the verification was successful. The model is significant.

The construct of interaction features a Cronbach alpha of $\alpha=0.869$ (13 items). All item scales were thus confirmed to be reliable. The according value could be assessed as good (Brosius, 2008).

The $\mathrm{R}^{2}$ value of 0.58 confirms a good prediction of the interaction by means of using the four activating functions of the mobile-learning application. The overall model is statistically significant (the significance level is less than 0.05), so it can be assumed that the predictors contribute to the explanation of the dependent variable (interaction). All regression coefficients (B) are positive, meaning that all independent variables positively affect each dependent variable.

The predictors Question Button, Co-Create Your Exam, and Peer Discussion contribute to the predictability of the criterion interaction. These three variables are significant in contributing to the prediction of the dependent variable. The independent variable Question Button is only marginally significant in this context. The beta value presented in the penultimate column of Table 5 confirms that Peer Discussion most significantly affects the interaction. Co-Create Your Exam provides the second largest contribution to the variance verification. Only the Panic Button does not independently contribute to the prediction of interaction. 
Table 5. Multiple linear regression for the prediction of interaction

\begin{tabular}{|c|c|c|c|c|}
\hline \multirow[t]{2}{*}{ Construct } & \multicolumn{2}{|c|}{ Non Standardized Coefficients } & \multirow{2}{*}{$\begin{array}{c}\text { Standardized Coefficients } \\
\text { Beta }\end{array}$} & \multirow[b]{2}{*}{$\mathbf{T}$} \\
\hline & B & Standard Error & & \\
\hline (Constant) & .939 & .375 & & 2.505 \\
\hline Question Button & .139 & .071 & .226 & $1.945^{*}$ \\
\hline Panic Button & .062 & .078 & .085 & .795 \\
\hline Co-Create Your Exam & .202 & .077 & .370 & $2.628 * *$ \\
\hline Peer Discussion & .209 & .074 & .400 & $2.824 * *$ \\
\hline
\end{tabular}

Comment: Multiple linear regression (method: inclusion). Predication of interaction: $\mathrm{R}^{2}=0.58$, corrected $\mathrm{R}^{2}=.545 ; \mathrm{F}(4,44)=15,362 ; \mathrm{p}$ $<.001 ; \mathrm{N}=49$.

The functions Co-Create Your Exam and Peer Discussion are directly implemented into the learningteaching-environment by the lecturer. In addition, these activating functions encourage the students to thoroughly reflect on the learning contents of the lecture. Additionally, both functions promote an ITmediated communication among the students as well as between the students and the lecturer, which constitutes a possible explanation for the fact that these two variables contribute more effectively to the prediction of interaction. In return, the Question and Panic Button are permanently available to the students in- and outside of class, but they are not actively implemented into the teaching by the lecturer. The tentative use of the Panic Button indicated by the mean value in Table 4 already suggests that this feature hardly contributes to predicting interaction. The use of the Question Button only slightly contributes to the prediction of the interaction, as suggested by the low mean value in Table 4. This low significance may be explained by the fact that the lecturer does not actively implement this function into the teaching, since it merely allows for a unidirectional communication between students and lecturer.

To sum up, three of the four activating functions of the mobile-learning application contribute to the prediction of interaction in the large-scale lecture.

\section{LIMITATIONS, FUTURE RESEARCH, AND CONCLUSION}

The evaluation results demonstrate that the use of the mobile-learning application positively affects the interaction in a university large-scale lecture. Since the data are gathered in a real setting, it cannot precisely prove that an increase in interaction will solely result from learners' use of the mobile-learning application during the learning-teaching process. A field study is subject to several confounders, so changes in interaction could also arise from other external effects (Coolican, 2014). Usually, the external validity is higher in field studies against a smaller internal validity. The interaction is a complex variable, difficult to measure, and can be affected by various effects - even outside the use of the mobilelearning application. By means of a text, the students were made aware of the fact that all questions and information in the online questionnaire were concerned with the mobile-learning application. Still, some students might have given statements on the lecture in general without directly referring to the mobile-learning application, constituting another limitation of the present study results. Another limitation of the research methodology is the self-selection bias (Gautier and Klaauw, 2012). Another issue that limits the results is regarding the response rate of $58 \%$. It is possible that only students who liked 
the mobile-learning application participated in the evaluation and the remaining $42 \%$ didn't like the mobile-learning application. This effect would bias and limits the results. However, after the evaluation had ended specific analyses of that cannot make.

The mobile-learning application is going to be established in the didactic concept of the IS introductory lecture. Additionally, the application is offered to other departments to conduct additional evaluations. The goal will be to extensively test the application and collect feedback for further development.

For the theoretical implication, the study contributes to the learners' activation and engagement in the learning-teaching process. Thus, the results contribute to the didactical theories of IS research by providing insights on a learner-centered approach integrating interaction into university large-scale lectures. The results can also be applied to further learning-teaching environments. The use of the mobile-learning application is valuable and enhances the didactical approach not only for university large-scale blended learning lectures, but also for e-learning lectures (e.g., massive open online courses (MOOCs)) (Janson et al., 2014) or traditional learning-teaching environments or other new contexts of interest.

The results of this paper are of practical relevance for researchers, lecturers, and practitioners alike, since they illustrate a way to use the mobile-learning application to time- and resource-efficiently support and enhance communication, exchange, and interaction in a large-scale lecture. According to service research (Leimeister, 2012), the concepts of IT support (Leimeister, 2014) as well as customer integration a scalability of university teaching is facilitated. The study reveals a way to engage and activate learners in large-scale lectures in spite of limited resources, specifically to address the interaction regarding the learners and the learning content, between the learners and the lecturer as well as the interaction among the learners themselves. The results indicate practical as well time- and resource-friendly guidelines for the design of large-scale lectures and at the same time antagonize the challenges of large-scale lectures.

\section{REFERENCES}

Alonso, F., Manrique, D., \& Viñes, J. M. (2009). A moderate constructivist e-learning instructional model evaluated on computer specialists. Computers \& Education, 53(1), 57-65. doi:10.1016/j.compedu.2009.01.002

Arbaugh, J. B. (2000). Virtual classroom characteristics and student satisfaction with internet-based MBA courses. Journal of Management Education, 24(1), 32-54. doi:10.1177/105256290002400104

Bitzer, P., Lehmann, K., Hirdes, E. M., \& Thillainathan, N. (2012). Managing the Masses - Developing an Educational Dashboard for Lecturers in Large-Scale Lectures. In European Conference on Information Systems (ECIS).

Bligh, D. A. (1998). What's the Use of Lectures? Eastbourne: Intellect books.

Briggs, R. O. (2006). On theory-driven design and deployment of collaboration systems. International Journal of Human-Computer Studies, 64(7), 573-582. doi:10.1016/j.ijhcs.2006.02.003

Brosius, F. (2008). SPSS 16: Hüthig Jehle Rehm.

Bryant, J., \& Heath, R. (2000). Human communication theory and research: concepts, contexts, and challenges. Mahwah, NJ: Lawrence Erlbaum Associates. 
Chin, W. W. (1998). The partial least squares approach for structural equation modeling. In G. A. Marcoulides (Ed.), Modern methods for business research (p. 437). Mahwah, NJ: Lawrence Erlbaum Associates Publishers.

Coolican, H. (2014). Research methods and statistics in psychology. New York, NY: Psychology Press.

Davis, F. D. (1989). Perceived usefulness, perceived ease of use, and user acceptance of information technology. Management Information Systems Quarterly, 13(3), 319-340. doi:10.2307/249008

Dawabi, P., Dietz, L., Fernandez, A., \& Wessner, M. (2003). Using PDAs to support face-to-face learning. In Computer Support for Collaborative Learning. Academic Press.

de Clunie, G. T., Serrão, T., Monteiro Braz, J.-L., Serrão, T., Rangel, N., \& Castillo, A. (2012). Developing an Android based learning application for mobile devices. In Telematics and Information Systems (EATIS), 6th Euro American Conference on. doi:10.1145/2261605.2261641

Dufresne, R. J., Gerace, W. J., Leonard, W. J., Mestre, J. P., \& Wenk, L. (1996). Classtalk: A classroom communication system for active learning. Journal of Computing in Higher Education, 7(2), 3-47. doi:10.1007/BF02948592

Duncan-Howell, J. A., \& Lee, K.-T. (2007). M-Learning-Innovations and Initiatives: Finding a place for mobile technologies within tertiary educational settings. Auckland.

Dyson, L. E., Litchfield, A., Raban, R., \& Tyler, J. (2009). Interactive classroom mLearning and the experiential transactions between students and lecturer. Ascilite.

Eom, S. B., Wen, H. J., \& Ashill, N. (2006). The Determinants of Students' Perceived Learning Outcomes and Satisfaction in University Online Education: An Empirical Investigation*. Decision Sciences Journal of Innovative Education, 4(2), 215-235. doi:10.1111/j.1540-4609.2006.00114.x

Evans, C., \& Gibbons, N. J. (2007). The interactivity effect in multimedia learning. Computers \&amp. Education, 49(4), 1147-1160.

Fagen, A. P., Crouch, C. H., \& Mazur, E. (2002). Peer instruction: Results from a range of classrooms. The Physics Teacher, 40, 206.

Gagné, E. D., Yekovich, C. W., \& Yekovich, F. R. (1993). The cognitive psychology of school learning. New York: HarperCollins College.

Gautier, P. A., \& Klaauw, B. (2012). Selection in a field experiment with voluntary participation. Journal of Applied Econometrics, 27(1), 63-84. doi:10.1002/jae.1184

Greenbaum, T. L. (1998). The handbook for focus group research. Thousand Oaks, CA: Sage.

Greene, W. H., \& Zhang, C. (2003). Econometric analysis. Prentice Hall.

Haake, J. M., \& Wessner, M. (2004). Kooperative Lernräume. In CSCL-Kompendium. Lehr- und Handbuch zum computerunterstützten kooperativen Lernen (pp. 109-117). München: Oldenbourg Wissenschaftsverlag GmbH. doi:10.1524/9783486593976 
Hardless, C., Nilsson, M., \& Nuldén, U. (2005). 'Copernicus' experiencing a failing project for reflection and learning. Management Learning, 36(2), 181-217. doi:10.1177/1350507605052557

Hevner, A. R., March, S. T., Park, J., \& Ram, S. (2004). Design science in information systems research. Management Information Systems Quarterly, 28(1), 75-105.

Hull, E., Jackson, K., \& Dick, J. (2010). Requirements engineering. Springer Science \& Business Media. Janson, A., Ernst, S.-J., Lehmann, K., \& Leimeister, J. M. (2014). Creating Awareness and Reflection in a Large-Scale IS Lecture-The Application of a Peer Assessment in a Flipped Classroom Scenario. In 4th Workshop on Awareness and Reflection in Technology-Enhanced Learning (ARTEL 2014) to be held in the context of EC-TEL 2014.

Johnson, L., Adams, S., \& Cummins, M. (2012). The NMC horizon report: 2012 higher education edition. Austin, TX: The New Media Consortium.

Kenwright, K. (2009). Clickers in the Classroom. TechTrends, 53(1), 74-77. doi:10.1007/s11528-0090240-7

Kolfschoten, G. L., \& De Vreede, G. J. (2009). A design approach for collaboration processes: A multimethod design science study in collaboration engineering. Journal of Management Information Systems, 26(1), 225-256. doi:10.2753/MIS0742-1222260109

Kopf, S., Haenselmann, T., Kiess, J., Guthier, B., \& Effelsberg, W. (2011). Algorithms for video retargeting. Multimedia Tools and Applications, 51(2), 819-861. doi:10.1007/s11042-010-0717-6

Kukulska-Hulme, A., \& Traxler, J. (2005). Mobile learning a handbook for educators and trainers. London: Routledge.

Lehmann, K., \& Leimeister, J.-M. (2015). Theory-driven Design of an IT-based Peer Assessment to Assess High Cognitive Levels of Educational Objectives in Large-scale Learning Services. In 23rd European Conference on Information Systems (ECIS 2015).

Lehmann, K., Oeste, S., Janson, A., Söllner, M., \& Leimeister, J. M. (2015). Flipping the Classroom - IT-unterstützte Lerneraktivierung zur Verbesserung des Lernerfolges einer universitären Massenlehrveranstaltung. HMD Praxis der Wirtschaftsinformatik, 1-15.

Lehmann, K., Thillainathan, N., Bitzer, P., \& Leimeister, J. M. (2012). Performance Dashboard für Dozenten in der universitären Lehre. In Multikonferenz der Wirtschaftsinformatik. Braunschweig, Deutschland: MKWI.

Leimeister, J. M. (2012). Dienstleistungsengineering und-management. Berlin, Heidelberg: Springer DE. doi:10.1007/978-3-642-27983-6

Leimeister, J. M. (2014). Collaboration Engineering. IT-gestützteZusammenarbeitsprozesse systematisch entwickeln und durchführen. Heidelberg Springer DE.

Liu, T.-C., Liang, J.-K., Wang, H.-Y., Chan, T.-W., \& Wei, L.-H. (2003). Embedding educlick in classroom to enhance interaction. In International conference on computers in education (ICCE). 
Moore, A., Masterson, J. T., Christophel, D. M., \& Shea, K. A. (1996). College Teacher Immediacy and Student Ratings of Instruction. Communication Education, 45(1), 29-39. doi:10.1080/03634529609379030

Moore, M. G. (1989). Editorial: Three types of interaction. American Journal of Distance Education, 3(2), 1-7. doi:10.1080/08923648909526659

Morgan, N., \& Saxton, J. (1991). Teaching, questioning, and learning. New York: Routledge.

Nielsen, J. (1994). Estimating the number of subjects needed for a thinking aloud test. International Journal of Human-Computer Studies, 41(3), 385-397. doi:10.1006/ijhc.1994.1065

Nunnally, J. C. (2010). Psychometric Theory 3E. New York: Tata McGraw-Hill Education.

Oliva, A., Mack, M. L., Shrestha, M., \& Peeper, A. (2004). Identifying the perceptual dimensions of visual complexity of scenes. In The 26th Annual Meeting of the Cogn. Sci. Soc.

Peffers, K., Tuunanen, T., Gengler, C. E., Rossi, M., Hui, W., \& Virtanen, V. (2006). The design science research process: a model for producing and presenting information systems research. In Proceedings of the First International Conference on Design Science Research in Information Systems and Technology (DESRIST 2006).

Picciano, A. G. (2002). Beyond student perceptions: Issues of interaction, presence, and performance in an online course. Journal of Asynchronous Learning Networks, 6(1), 21-40.

Pilemalm, S., \& Timpka, T. (2008). Third generation participatory design in health informatics-Making user participation applicable to large-scale information system projects. Journal of Biomedical Informatics, 41(2), 327-339. doi:10.1016/j.jbi.2007.09.004

Ratto, M., Shapiro, R. B., Truong, T. M., \& Griswold, W. G. (2003). The ActiveClass project: Experiments in encouraging classroom participation. In Computer support for collaborative learning. doi:10.1007/978-94-017-0195-2_57

Reinhardt, W., Sievers, M., Magenheim, J., Kundisch, D., Herrmann, P., \& Beutner, M. (2012). “PINGO: peer instruction for very large groups. In Seventh European Conference on Technology Enhanced Learning. doi:10.1007/978-3-642-33263-0_51

Roschelle, J., Patton, C., \& Pea, R. (2002). To unlock the learning value of wireless mobile devices, understand coupling. In Wireless and Mobile Technologies in Education. doi:10.1109/WMTE.2002.1039214

Roth, W. M., McGinn, M. K., Woszczyna, C., \& Boutonne, S. (1999). Differential participation during science conversations: The interaction of focal artifacts, social configurations, and physical arrangements. Journal of the Learning Sciences, 8(3-4), 293-347. doi:10.1080/10508406.1999.9672073

Scheele, N., Wessels, A., \& Effelsberg, W. (2004). Die interaktive Vorlesung in der Praxis. In DeLFI 2004: Die 2. e-Learning Fachtagung Informatik.

Schon, D., Klinger, M., Kopf, S., \& Effelsberg, W. (2012). MobileQuiz-A Lecture Survey Tool using Smartphones and QR Tags. International Journal of Digital Information and Wireless Communications, 2(3), 231-244. 
Schrum, L., \& Berge, Z. L. (1997). Creating Student Interaction within the Educational Experience: A Challenge for Online Teachers. Canadian Journal of Educational Communication, 26(3), 133-144.

Shotsberger, P. G., \& Vatter, R. (2001). Teaching and learning in the wireless classroom. Computer, 34(3), 110-111. doi:10.1109/2.910902

Siau, K., Sheng, H., \& Fui-Hoon Nah, F. (2006). Use of a classroom response system to enhance classroom interactivity. IEEE Transactions on Education, 49(3), 398-403. doi:10.1109/TE.2006.879802

Sims, R. (2003). Promises of interactivity: Aligning learner perceptions and expectations with strategies for flexible and online learning. Distance Education, 24(1), 87-103. doi:10.1080/01587910303050

Smith, B. (2001). Just give us the right answer. In H. Edwards, B. Smith, \& G. Webb (Eds.), Lecturing: Case studies, experience and practice (pp. 123-129). London: Kogan.

Snell, Y. S., \& Linda, S. (1999). Interactive lecturing: Strategies for increasing participation in large group presentations. Medical Teacher, 21(1), 37-42. doi:10.1080/01421599980011

Söllner, M., Hoffmann, A., Hoffmann, H., Wacker, A., \& Leimeister, J. M. (2012). Understanding the Formation of Trust in IT Artifacts. In The International Conference on Information Systems (ICIS).

Tabata, Y., Yin, C., Ogata, H., \& Yano, Y. (2010). An iPhone quiz system for learning foreign languages. In Informatics in Control, Automation and Robotics (CAR), 2010 2nd International Asia Conference on. doi:10.1109/CAR.2010.5456691

Thurmond, V., \& Wambach, K. (2004). Understanding interactions in distance education: A review of the literature. International Journal of Instructional Technology and Distance Learning, 1(1), 9-26.

Van Rijsselbergen, D., Poppe, C., Verwaest, M., Mannens, E., \& Van de Walle, R. (2012). Semantic Mastering: Content adaptation in the creative drama production workflow. Multimedia Tools and Applications, 59(1), 307-340. doi:10.1007/s11042-010-0710-0

VanDeGrift, T., Wolfman, S. A., Yasuhara, K., \& Anderson, R. J. (2002). Promoting interaction in large classes with a computer-mediated feedback system. In Computer Science Department and Microsoft Research.

Venkatesh, V., Morris, M. G., Gordon, B. D., \& Davis, F. D. (2003). User Acceptance of Information Technology: Toward a Unified View. Management Information Systems Quarterly, 27(3), 425-478.

Wang, M. C., Haertel, G. D., \& Walberg, H. J. (1990). What influences learning? A content analysis of review literature. The Journal of Educational Research, 84(1), 30-43. doi:10.1080/00220671.1990 .10885988

Wells, J. D., Valacich, J. S., \& Hess, T. J. (2011). What signal are you sending? how website quality influences perceptions of product quality and purchase intentions. Management Information Systems Quarterly, 35(2), 373-396.

Wessner, M., \& Dawabi, P. (2004). Interaktionsunterstützung für die Präsenzlehre-Szenarien und Design. In DeLFI 2004: Die 2. e-Learning Fachtagung Informatik. 
Wortmann, F., Hirdes, E. M., Lehmann, K., \& Zülich, J. (2014). IT-Unterstützung von Blended Learning Konzepten. In K. Möller \& W. Schultze (Eds.), Produktivität von Dienstleistungen. Wiesbaden: Springer Gabler.

Yigitbasioglu, O. M., \& Velcu, O. (2011). A review of dashboards in performance management: Implications for design and research. International Journal of Accounting Information Systems.

Ziegler, M., \& Bühner, M. (2009). Statistik für Psychologen und Sozialwissenschaftler. Pearson Deutschland $\mathrm{GmbH}$. 